\title{
Analysis of Environmental Impacts of Solar Energy Technologies in Rwanda: GigaWatt
}

\author{
Eustache Hakizimana $^{1, *}$, A. Ngendahayo ${ }^{1}$, U. G. Wali ${ }^{2}$, D. Sandoval ${ }^{1}$, V. Kayibanda ${ }^{3}$ \\ ${ }^{1}$ African Center of Excellence in Energy for Sustainable Development, University of Rwanda, Rwanda \\ ${ }^{2}$ Department of Civil, Environmental and Geomatics Engineering, University of Rwanda, Rwanda \\ ${ }^{3}$ Department of Mechanical and Energy Engineering, School of Engineering, University of Rwanda, Rwanda
}

Received March 17, 2020; Revised April 20, 2020; Accepted May 3, 2020

Copyright $\mathrm{O} 2020$ by authors, all rights reserved. Authors agree that this article remains permanently open access under the terms of the Creative Commons Attribution License 4.0 International License

\begin{abstract}
Nowadays Rwanda's target is to transit from a developing country to a middle-income country. One of the objectives to achieve this is the government encouraging private companies and individuals to invest in solar energy use either solar home system, mini-grid or grid-connected technology. The main objective of the study was to investigate the environmental impact assessment of solar energy technologies in Rwanda and its related plant performances. The assessment of the Rwamagana solar power plant (GigaWatt) was defined as a case study. In this study, the data and information were collected from the rural community of Rwamagana district, power plant and Rwanda energy group (REG). The Rwanda national electrification framework shows that solar energy technology is the third after hydropower, thermal and peat technologies. Solar PV modules used to produce electricity of $8.5 \mathrm{MW}$ to the national grid while more than 14,970 solar home systems are installed in different parts of Rwanda. As shown in the presented results, there were no global warming emissions associated with generating electricity from solar energy technologies while Rwamagana solar power plant used larger utility-scale solar photovoltaic panels to raise the land degradation and habitat loss. The paper is concluded focusing on the ways to avoid negative and enhance the positive impacts of solar energy technology in the selected power plant.
\end{abstract}

Keywords Solar Energy Technology, Solar Photovoltaic, Solar Home System and Rural Electrification

\section{Introduction}

Rwanda has an electricity generation capacity of
224.6MW (in 2019) where most of this power comes from different power plants such as hydro (47\%), thermal $27 \%$ (Diesel and Heavy fuel generators), solar PV (5\%) and methane (14. \%). Based on current data, as of December 2019 , the cumulative connectivity rate is $52.8 \%$ of Rwandan households, including $38.5 \%$ connected to the national grid and $14.3 \%$ accessing through off-grid systems (mainly solar). The U.S. National Air and Space Agency (NASA), as well as the University of Rwanda, assessed Rwanda's solar radiation and solar resources. Rwanda's Eastern Province has the greatest potential for generating energy from solar resources. Another academic assessment, undertaken in partnership with the MININFRA Department of Meteorology in 2007, used a meteorological data set to estimate monthly averaged global solar radiation [1].

Rwanda's daily solar irradiation ranges from $4 \mathrm{kWh} / \mathrm{m}^{2}$ north of the city of Ruhengeri to $5.4 \mathrm{kWh} / \mathrm{m}^{2}$ south of the capital, Kigali, in the Southern and Eastern provinces. However, conditions vary from season to season, with average daily irradiation levels in the cloud reaching about $4.5 \mathrm{kWh} / \mathrm{m}^{2}$ and It estimates the total annual potential to be around $66.8 \mathrm{TWh}$ [1]. Rwanda is well benefited with solar energy, even during the months of the rainy seasons there is daily and sufficient sunshine, especially in the Eastern province, which is known for high irradiance values as it is indicated in Figure 1, the average daily global solar irradiation on the tilted surface has been estimated to be 5.2 $\mathrm{kWh}$ per $\mathrm{m}^{2}$ per day from Photovoltaic Geography Information System (PVGIS). The long-term monthly average daily global irradiation ranges from $4.8 \mathrm{kWh} /\left(\mathrm{m}^{2}\right.$ day) (location Burera, the month of May) of to $5.8 \mathrm{kWh} /$ ( $\mathrm{m}^{2}$ day) (location Nyanza, the month of July) which shows good potential for solar energy development [1]. 


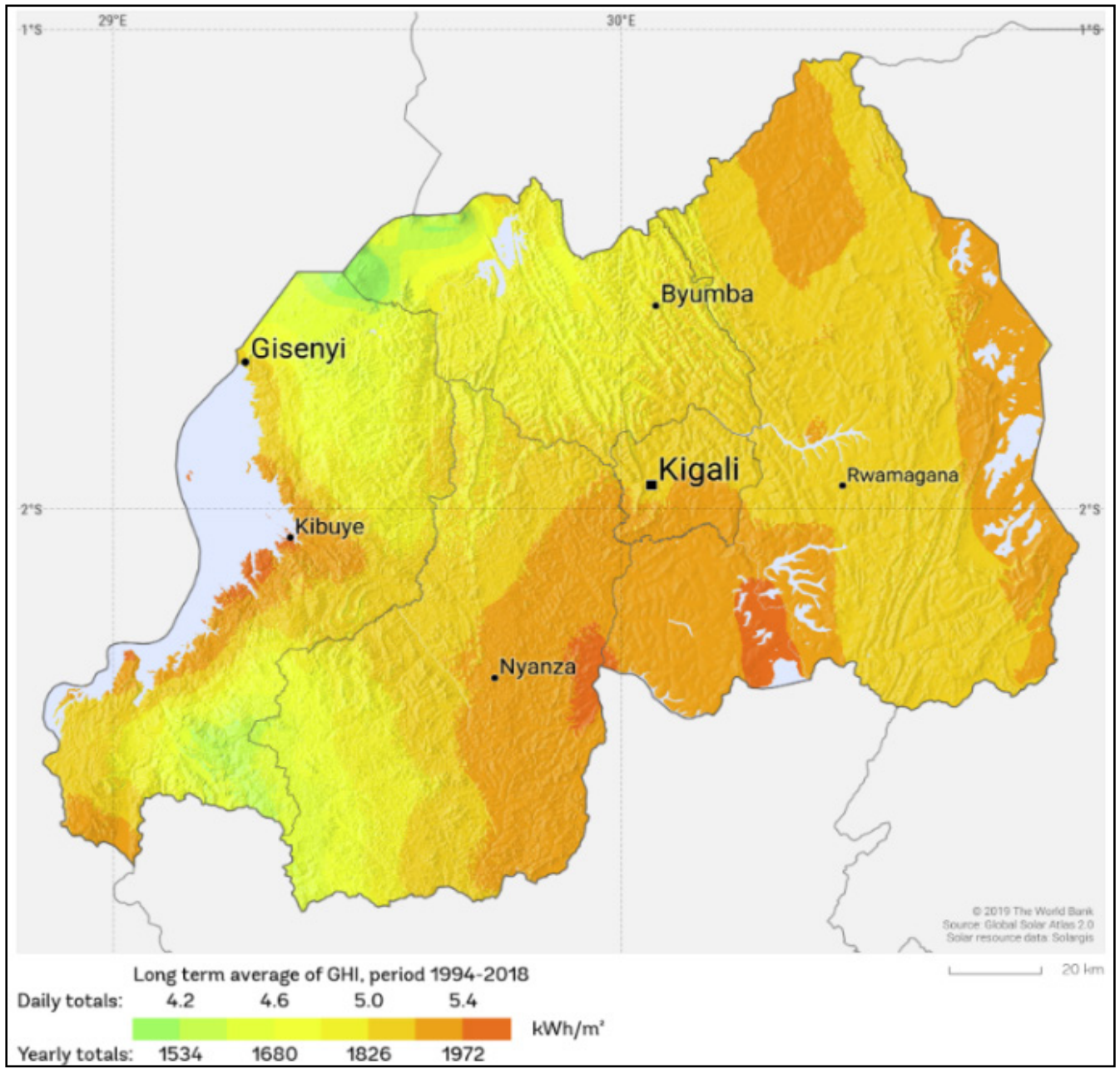

Figure 1. Global horizontal irradiation map for different districts of Rwanda [2]

\section{Current Status of Solar Energy Technology in Rwanda}

Rwanda is located in East Africa at approximately two degrees below the equator. It is generally characterized by Savannah climate and its geographic location endows it with sufficient solar radiation intensity approximately equal to $5 \mathrm{kWh} / \mathrm{m}^{2} /$ day and peak sun hours of approximately 5 hours per day. Rwanda's Total on-grid installed solar energy is $12.25 \mathrm{MW}$ as shown in Table 1 . Households far away from the planned national grid coverage are encouraged to use standalone solar photovoltaic (PVs) to reduce the cost of access to electricity. The Energy sector strategic plan underscores the universal access to electricity by 2024 with $48 \%$ of the households connected through off-grid power systems [5]. Using solar energy technology to power mini-grids are an excellent way to bring electricity access to people who do not live near power transmission lines with excellent solar energy resources. The location of all solar energy technologies are shown in figure 3. The output from the solar panel is in direct current. To use the output for use home appliances, the direct current must be converted into alternating current through an inverter. In the system shown in figure 2, the solar panel is connected to the home electric circuit by way of an inverter. When there is excess output, the surplus may be sold to an electric company. In the case, wattmeter for sale is installed in addition to wattmeter for purchase. Solar panels have a lifespan of roughly 30 years and come in a variety of shades depending on the type of material used in manufacturing. With a potential of $4.5 \mathrm{kWh}$ per $\mathrm{m}^{2}$ per day and approximately 5 peak sun hours, solar energy has a huge potentiality in Rwanda. The country has already engaged private sector participation in solar solutions as a lighting substitute for remote areas. Over 258,414 households have benefited from access to electricity with solar energy through Independent Power Producers countrywide. It encourages households located far away from the planned national grid coverage to use Mini-grid Solar Photovoltaics (PVs) to reduce the cost of access to electricity [20]. Solar Water Heater (SWH) technology was initiated in 2009 with the support of development partners and was formally launched in March 2012 with a pilot phase of 100 SWHs. Loans and grants are used to subsidize the cost of purchasing a SWH. Implementation started in April 2013 
and 2,256 SWHs have been installed in different households across the country [6]. Briefly, Solar water heating systems use free heat from the sun to warm domestic hot water. A conventional boiler or immersion heater can make the water hot or to provide hot water when solar energy is unavailable.

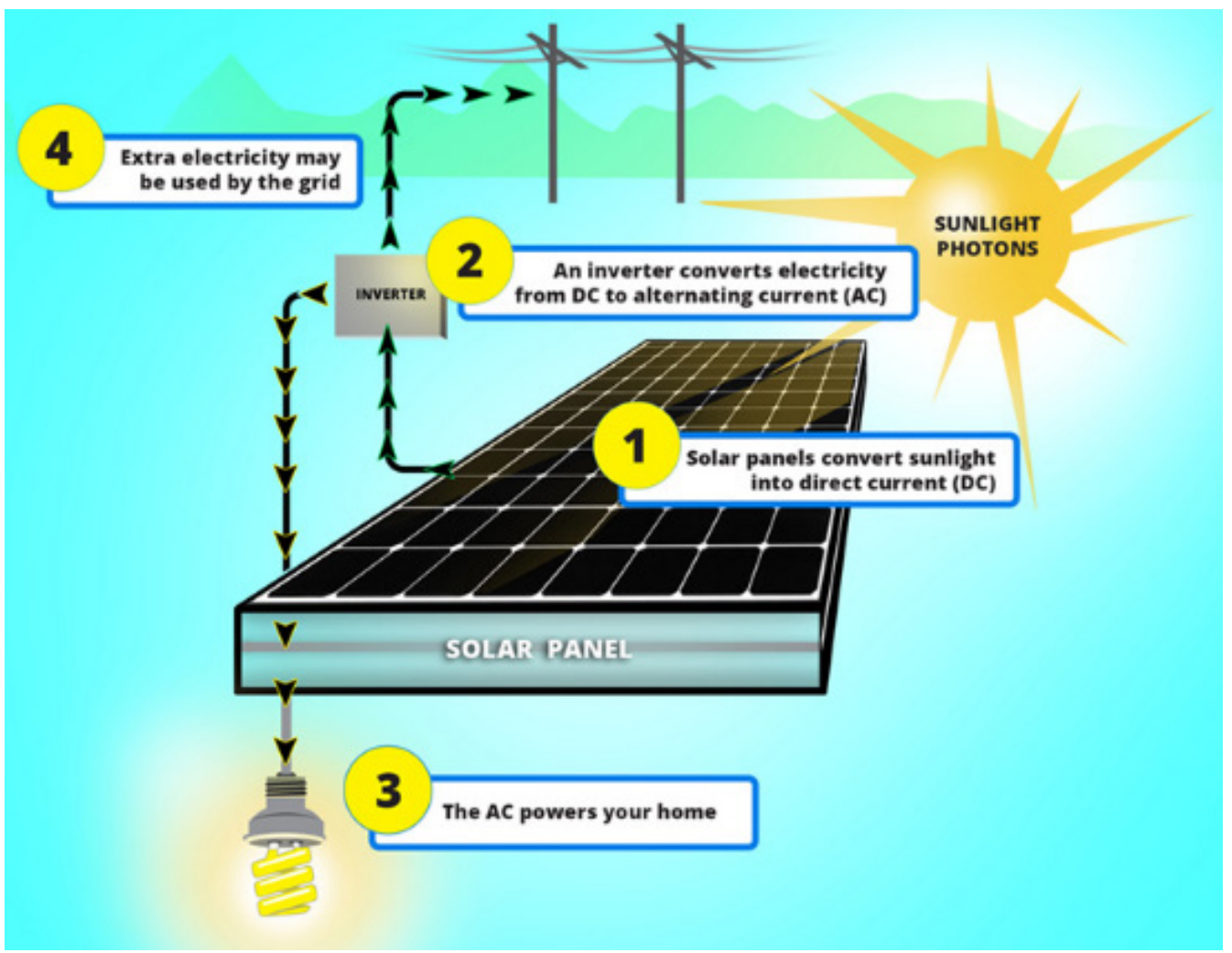

Figure 2. Working principle of solar Photovoltaic technology [3,4]

Table 1. Current solar energy technology in Rwanda [7]

\begin{tabular}{|c|c|c|c|c|c|c|c|c|c|}
\hline \multirow{2}{*}{$\begin{array}{l}\mathbf{N} / \\
\mathbf{S}\end{array}$} & \multirow{2}{*}{$\begin{array}{l}\text { Plant } \\
\text { Name }\end{array}$} & \multirow{2}{*}{$\begin{array}{c}\text { Installed } \\
\text { Capacity } \\
\text { (MW) }\end{array}$} & \multirow{2}{*}{$\begin{array}{c}\text { Capacity } \\
\text { Factor } \\
(\%)\end{array}$} & \multirow{2}{*}{ Ownership } & \multirow{2}{*}{$\begin{array}{c}\text { Operation } \\
\text { Date }\end{array}$} & \multirow{2}{*}{$\begin{array}{c}\text { Type of } \\
\text { Technology }\end{array}$} & \multirow{2}{*}{ Category } & \multicolumn{2}{|c|}{ Geographical Location } \\
\hline & & & & & & & & Latitude & Longitude \\
\hline 1 & Jali & 0.25 & 14 & $\begin{array}{c}\text { Mainz } \\
\text { Stadwerke/ } \\
\text { Local } \\
\text { Agency }\end{array}$ & 2007 & Solar & $\begin{array}{l}\text { On-grid } \\
\text { system }\end{array}$ & -1.88476 & 30.01614 \\
\hline 2 & Gigawatt & 8.50 & 14 & $\begin{array}{c}\text { Gigawatt } \\
\text { Global }\end{array}$ & 2013 & Solar & $\begin{array}{l}\text { On-grid } \\
\text { system }\end{array}$ & -2.026111 & 30.377222 \\
\hline 3 & $\begin{array}{c}\text { Nyamata } \\
\text { Solar }\end{array}$ & 0.03 & 35 & $\begin{array}{c}\text { NMEC } \\
\text { Nyamata }\end{array}$ & 2009 & Solar & $\begin{array}{l}\text { On-grid } \\
\text { system }\end{array}$ & -2.1458 & 30.09329 \\
\hline 4 & $\begin{array}{c}\text { Nasho } \\
\text { Solar PP }\end{array}$ & 3.30 & 20 & $\begin{array}{l}\text { Government } \\
\text { of Rwanda }\end{array}$ & 2017 & Solar & $\begin{array}{l}\text { On-grid } \\
\text { system }\end{array}$ & -1.884025 & 30.01638 \\
\hline \multicolumn{2}{|r|}{ Total } & \multicolumn{8}{|c|}{12.25} \\
\hline \multicolumn{10}{|c|}{ Mini-grid solar power plant } \\
\hline \multicolumn{3}{|c|}{ Name } & \multicolumn{3}{|c|}{ Location } & \multicolumn{4}{|c|}{ Generation Capacity } \\
\hline 1 & \multicolumn{2}{|c|}{ NESELTECK } & & \multicolumn{2}{|c|}{ Kirehe District } & \multicolumn{4}{|c|}{$30 \mathrm{KW}$} \\
\hline 2 & \multicolumn{2}{|c|}{ RENERG } & & \multicolumn{2}{|c|}{ Nyamasheke District } & \multicolumn{4}{|c|}{$30 \mathrm{KW}$} \\
\hline
\end{tabular}




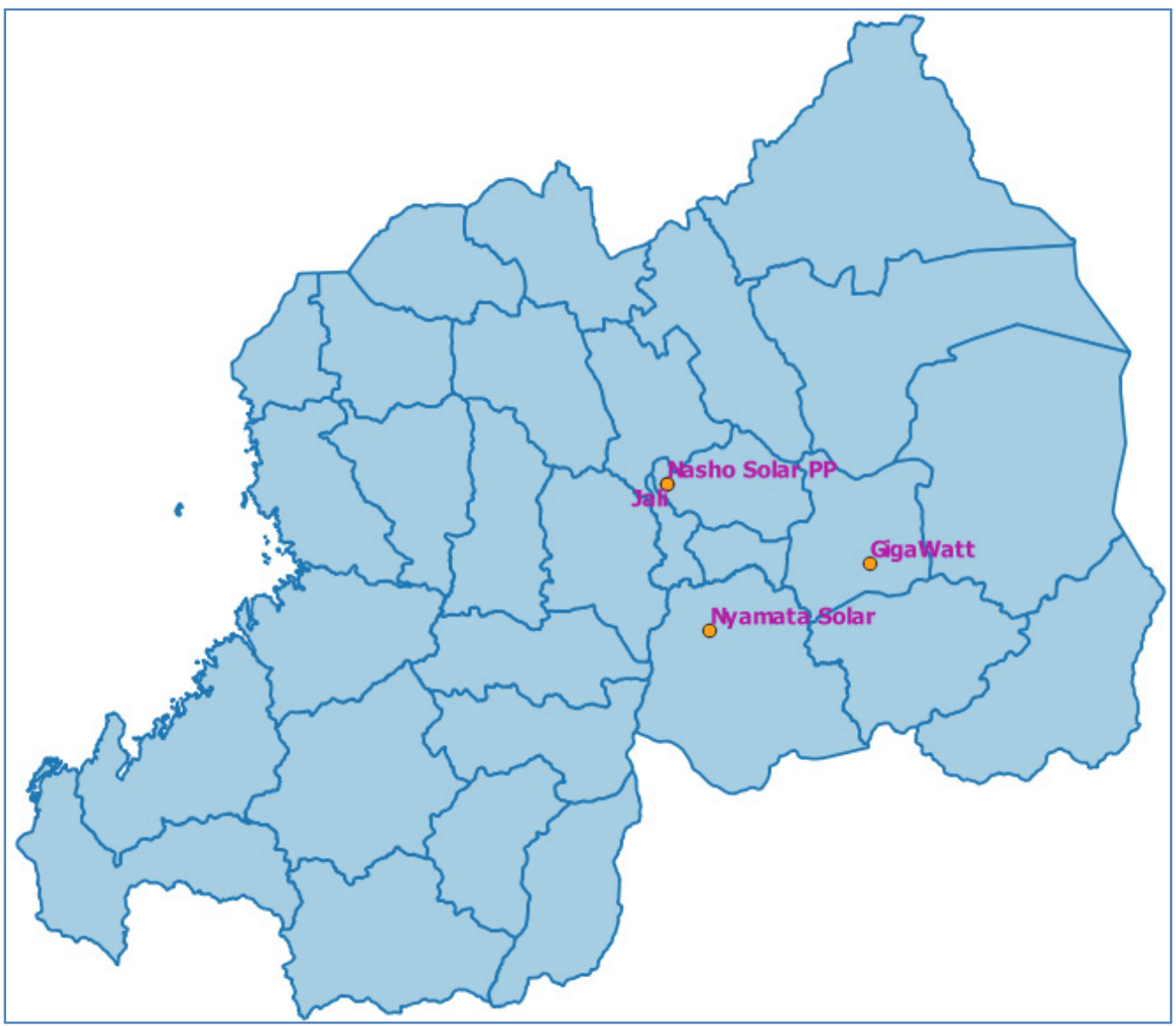

Figure 3. Location of all solar power plants in Rwanda

\section{Data Collection and Selected Site}

\subsection{The Proposed Power Plant Location}

The Rwamagana solar power plant is located on leased land as shown in figure 4, at the campus of the Agahozo Shalom Youth Village, in Rwamagana District, Eastern Rwanda, approximately 58 kilometers (36 mi), by road, southeast of Kigali, the capital and largest city in the country. The coordinates of the power station are: $2^{\circ} 01^{\prime} 34.0^{\prime \prime} \mathrm{S}, 30^{\circ} 22^{\prime} 38.0^{\prime \prime} \mathrm{E}$ (Latitude: 2.026111; Longitude: 30.377222). This solar power plant is 17 hectares of land and uses 28,360 photovoltaic panels and produces $8.5 \mathrm{MW}$ of grid-connected power to power 15,000 homes. The plant is the second large-scale solar field in East Africa, a field that is now providing approximately $6 \%$ of the total electrical supply of the country.
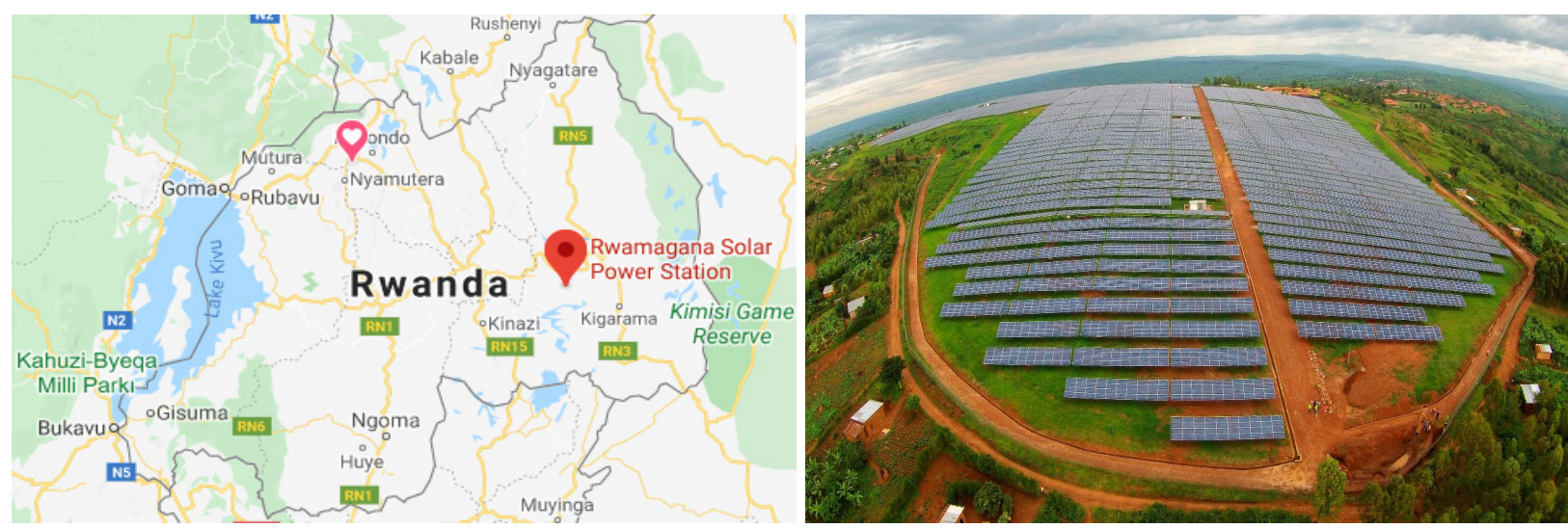

Figure 4. Location of Rwamagana Solar Power Plant 


\subsection{Collected Data and Information}

The data and information were collected by visiting the plant to talk to the employees who work there and knowing how the plant works. They showed me the main activities are doing in their plant and discussed how to increase the power plant performance. The physical assessment of the Rwamagana solar power plant focused on the following parameters: Survey the local climatic conditions and focus on the current power plant performance (Table 3). The occupant of the area before installing the plant, the environmental impact of the PV technology, the social-economic impact of the plant on the local community and the effect of maintenance on the environment. The inverter input voltage is $700 \mathrm{~V}$ DC with an output voltage of $415 \mathrm{~V}$ AC between lines. The inverter input voltage leads to formation of PV strings by connecting twenty PV modules in series. Figure 9 shows how the data are collected using different instruments. The step-up transformer is connected between the national grid lines and the inverter, and steps up the voltage from $0.415 \mathrm{kV}$ to $15 \mathrm{kV}$. The thermal scanner was used as faster equipment to check the temperature irregularities on solar panels in service. Any solar panel presenting abnormal working temperature may affect the output voltage and power of the whole string in which it is installed, consequently once identified, it will be replaced. The meteorology data are summarized in Table 4 and then the characteristic of photovoltaic modules are shown in the table 2 .

Table 2. Photovoltaic cell/module/array performance parameters

\begin{tabular}{|c|c|c|c|c|c|}
\hline $\mathbf{S} / \mathbf{N}$ & Parameter & Descriptions & Notation & Quantity & Units \\
\hline 1 & $\begin{array}{l}\text { Open circuit } \\
\text { voltage }\end{array}$ & $\begin{array}{l}\text { It is a maximum allowable voltage developed in a PV module } \\
\text { when an open circuit test is performed on it. }\end{array}$ & Voc & 45.19 & Volts (V) \\
\hline 2 & $\begin{array}{l}\text { Short circuit } \\
\text { current }\end{array}$ & $\begin{array}{l}\text { It is a maximum allowable current developed in a PV module } \\
\text { when a short circuit is performed on it by connecting a wire with } \\
\text { both the terminals. }\end{array}$ & Isc & 8.83 & $\begin{array}{l}\text { Amps } \\
\text { (A) }\end{array}$ \\
\hline 3 & $\begin{array}{l}\text { Maximum } \\
\text { voltage }\end{array}$ & $\begin{array}{l}\text { It is the } x \text { co-ordinate of maximum power point that is identified } \\
\text { in the I-V curve of the photovoltaic module that is drawn after } \\
\text { monitoring the data }\end{array}$ & Vmp & 35.97 & Volts (V) \\
\hline 4 & $\begin{array}{l}\text { Maximum } \\
\text { current }\end{array}$ & $\begin{array}{l}\text { It is the y co-ordinate of maximum power point that is identified } \\
\text { in the I-V curve of the photovoltaic module that is drawn after } \\
\text { monitoring the data }\end{array}$ & Imp & 8.34 & $\begin{array}{l}\text { Amps } \\
\text { (A) }\end{array}$ \\
\hline 5 & $\begin{array}{c}\text { Maximum } \\
\text { Power/peak }\end{array}$ & $\begin{array}{l}\text { Maximum power is the product of the maximum voltage and } \\
\text { current recorded for a monitoring duration. Ensuring maximum } \\
\text { power through the PV system is essential }\end{array}$ & $\mathrm{Pm}$ & 300 & $\begin{array}{l}\mathrm{W} \text { or } \mathrm{kW} \\
\text { or } \mathrm{MW}\end{array}$ \\
\hline 6 & $\begin{array}{l}\text { Working } \\
\text { temperature }\end{array}$ & $\begin{array}{l}\text { With the continuous exposure of the sunlight on to the PV } \\
\text { module throughout a day is responsible for the increase in PV } \\
\text { module temperatures }\end{array}$ & $\mathrm{T}$ & 45 & $0 \mathrm{C}$ \\
\hline 7 & Fill Factor & $\begin{array}{l}\text { It is an essential parameter that is named to be one of the } \\
\text { essential parameters that define the quality of the PV module } \\
\text { during the performance investigation. }\end{array}$ & $\mathrm{FF}$ & 0.7518 & - \\
\hline 8 & $\begin{array}{l}\text { Performance } \\
\text { Ratio }\end{array}$ & $\begin{array}{l}\text { Performance ratio is the parameter that represents overall PV } \\
\text { system performance considering all the effecting parameters }\end{array}$ & PR & - & $\%$ \\
\hline
\end{tabular}

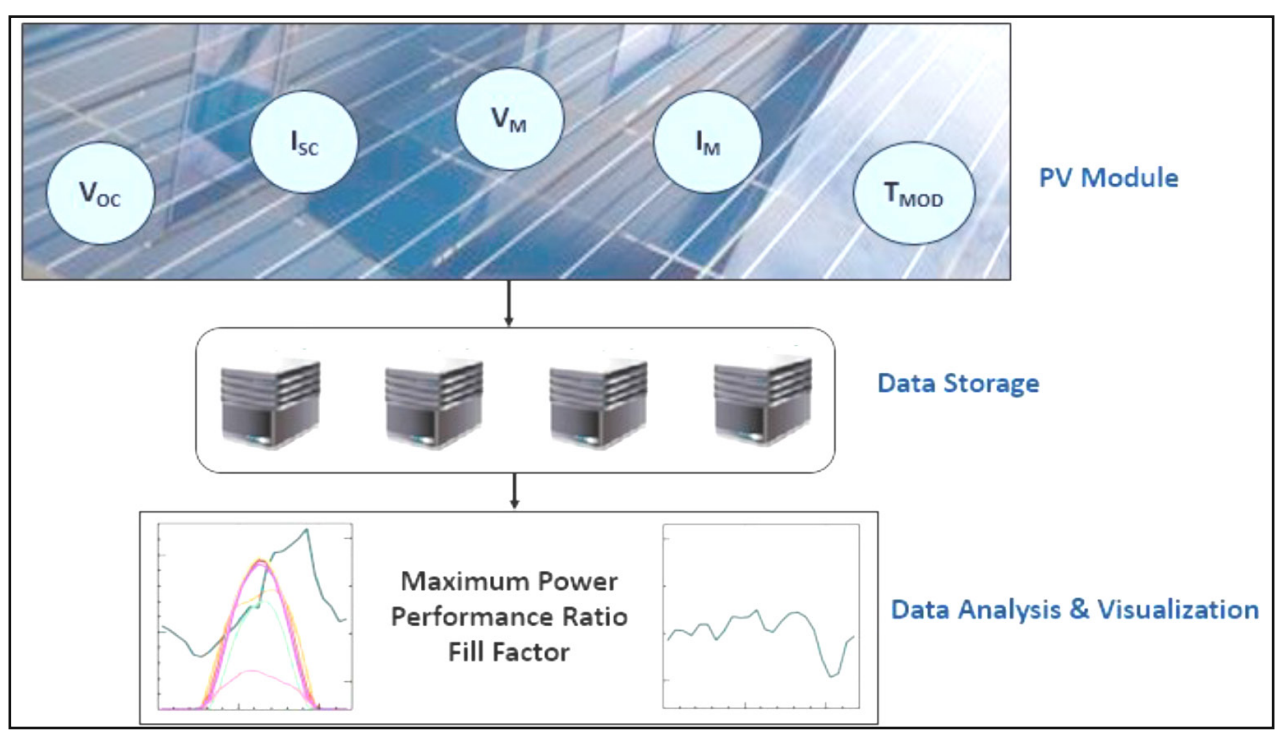

Figure 5. Schematic view of monitoring methodology for PV module 
Table 3. Performance of Rwamagana Solar power plant

\begin{tabular}{|c|c|c|c|c|c|c|c|c|c|c|c|c|}
\hline \multicolumn{13}{|c|}{ Year 2018} \\
\hline Months & Jan. & Feb. & Mar & Apr. & May & Jun & Jul & Aug. & Sept & Oct. & Nov. & Dec \\
\hline $\begin{array}{c}\text { Number } \\
\text { days }\end{array}$ & 31 & 28 & 31 & 30 & 31 & 30 & 31 & 31 & 30 & 30 & 30 & 31 \\
\hline Total hours & 744 & 627 & 744 & 720 & 744 & 720 & 744 & 744 & 720 & 720 & 720 & 744 \\
\hline $\begin{array}{l}\text { Installed } \\
\text { capacity } \\
(\mathrm{kWh})\end{array}$ & $6,324,000$ & $5,712,000$ & $6,324,000$ & $6,120,000$ & $6,324,000$ & $6,120,000$ & $6,324,000$ & $6,324,000$ & $6,120,000$ & $6,120,000$ & $6,120,000$ & $6,324,000$ \\
\hline $\begin{array}{c}\text { Generation } \\
\text { capacity } \\
(\mathrm{kWh})\end{array}$ & $1,041,000$ & $1,048,000$ & $1,041,000$ & 945,000 & $1,126,000$ & $1,325,000$ & $1,358,000$ & $1,126,490$ & $1,139,620$ & $1,174,260$ & $1,049,450$ & 980,810 \\
\hline $\begin{array}{l}\text { Plant load } \\
\text { factor }\end{array}$ & 16.46110057 & 18.34733894 & 16.46110057 & 15.44117647 & 17.80518659 & 21.6503268 & 21.47375079 & 17.81293485 & 18.62124183 & 19.1872549 & 17.14787582 & 15.50932954 \\
\hline \multicolumn{13}{|c|}{ Year 2019} \\
\hline Months & Jan. & Feb. & Mar & Apr. & May & Jun & Jul & Aug. & Sept & Oct. & Nov. & Dec \\
\hline $\begin{array}{c}\text { Number } \\
\text { days }\end{array}$ & 31 & 28 & 31 & 30 & 31 & 30 & 31 & 31 & 30 & 30 & 30 & 31 \\
\hline $\begin{array}{l}\text { Installed } \\
\text { capacity } \\
\text { (MW) }\end{array}$ & \multicolumn{12}{|c|}{8.5} \\
\hline $\begin{array}{c}\text { Available } \\
\text { capacity } \\
\text { (MW) }\end{array}$ & \multicolumn{12}{|c|}{7.7} \\
\hline $\begin{array}{c}\text { Generation } \\
\text { Capacity } \\
\text { (MWh) }\end{array}$ & $1,215.10$ & $1,052.40$ & $1,119.79$ & $1,112.33$ & $1,037.09$ & $1,044.74$ & $1,189.45$ & $1,144.99$ & $1,104.60$ & $1,058.44$ & $1,037.09$ & $1,189.45$ \\
\hline
\end{tabular}




\subsection{Rwamagana Solar Energy and Surface Meteorology}

The monthly average amount of the total solar radiation incident on a horizontal surface on the surface of the earth in a month averaged for that month over the 22-year period (Jul 1983 - Jun 2005). Each monthly averaged value is evaluated as the numerical average of 3-hourly values for the month. The monthly average amount of the total solar radiation incident on a horizontal surface on the surface of the earth divided by the monthly average incoming top-of-atmosphere insolation for a month averaged for that month over the 22-year period (Jul 1983 - Jun 2005); (i.e. Clearness index is the fraction of insolation at the top of the atmosphere which reaches the surface of the earth). $0=$ very overcast and $1=$ sunny [8]. The monthly average air temperature for a month averaged for that month over the 22-year period (Jan 1983 - Dec 2004). Temperature values are about 10 meters above the surface of the earth. Each monthly averaged value is evaluated as the numerical average of 3-hourly values for the month. The monthly average wind speed for a month averaged for that month over the 10-year period (July 1983 - June 1993). The wind speed values are about 50 meters above the surface of the earth. Each monthly averaged value is evaluated as the numerical average of 3-hourly values for the given month [8]. The monthly average precipitation for a given month averaged for that month over the period from 1961 to 1990 and the number of days per month with precipitation $>0.1$ $\mathrm{mm}$ [9]. Figure 7 shows the location's sunrise, sunset, dawn and dusk times for the whole year. The start of down and the end of dusk times are based on the definition of "civil twilight" [10].

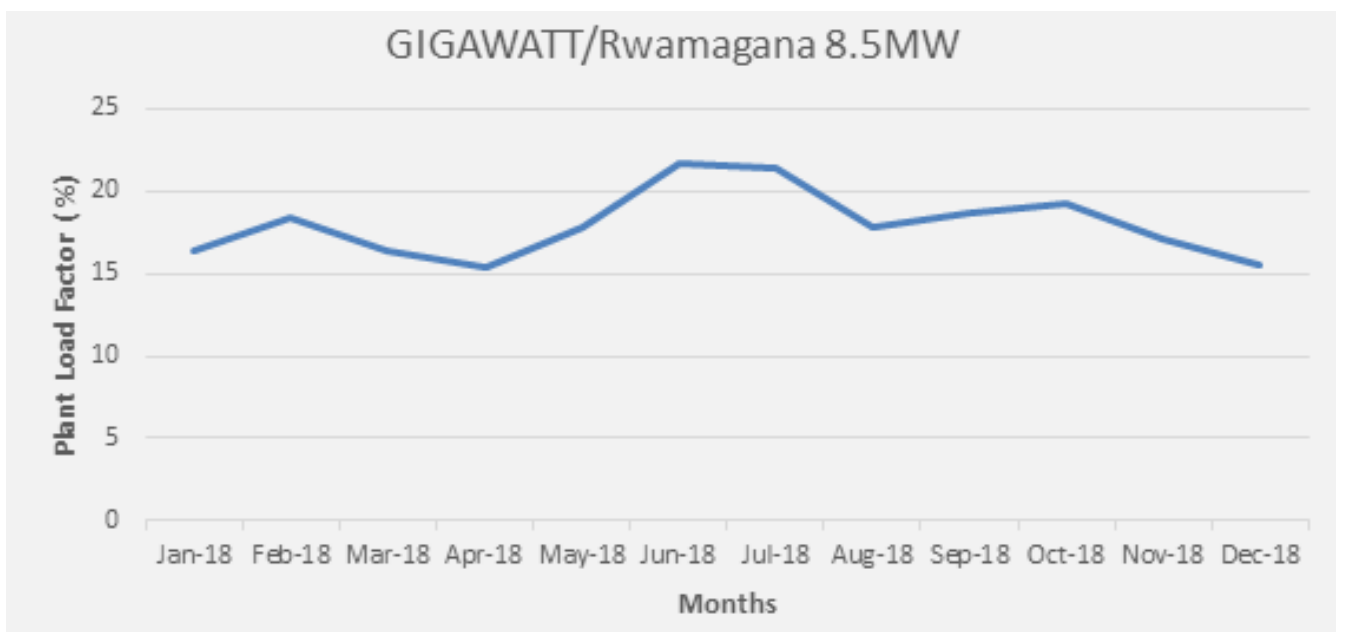

Figure 6. Plant load factor per month in 2018

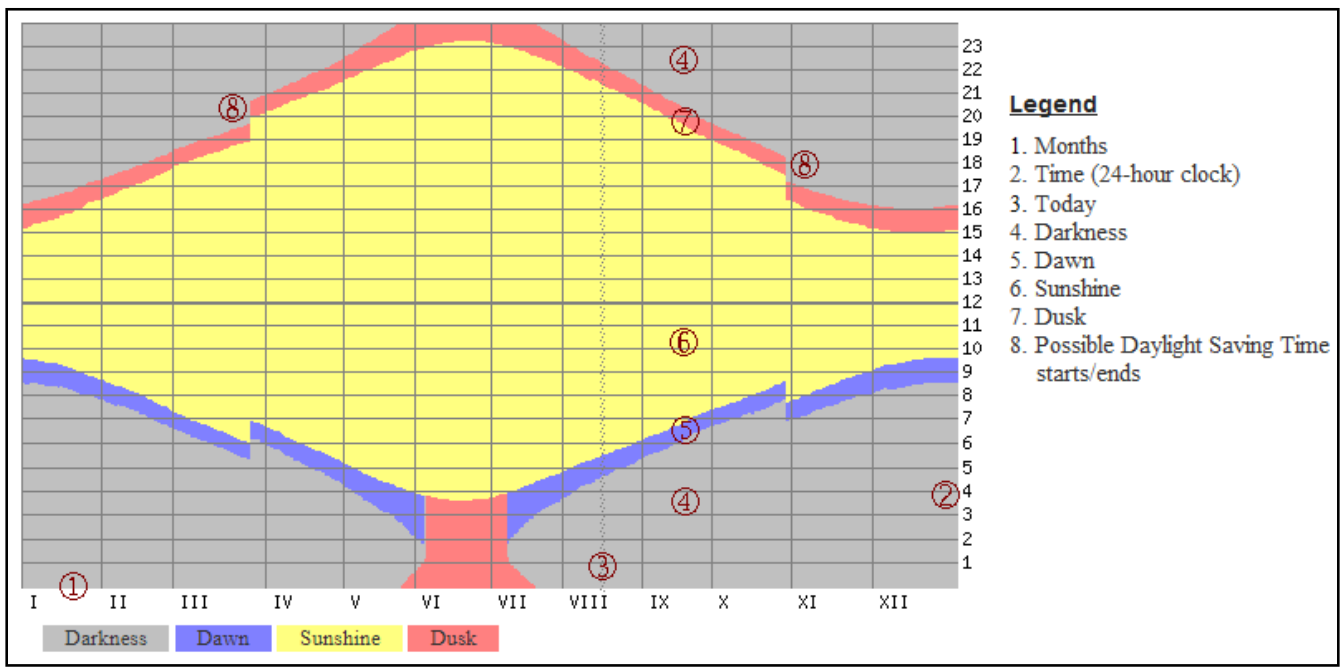

Figure 7. Graph of Sunrise, sunset, dawn and dusk times in Rwamagana 
Table 4. Solar energy and surface meteorology

\begin{tabular}{|c|c|c|c|c|c|c|c|c|c|c|c|c|}
\hline Variable & Jan. & Feb. & Mar & Apr & May & Jun & Jul & Aug & Sept. & Oct. & Nov. & Dec. \\
\hline $\begin{array}{c}\text { Insolation, } \\
\mathrm{kWh} / \mathrm{m}^{2} / \mathrm{day}\end{array}$ & 4.63 & 4.87 & 4.65 & 4.48 & 4.48 & 4.63 & 4.95 & 4.85 & 4.82 & 4.39 & 4.26 & 4.36 \\
\hline Clearness, $-1^{-1}$ & 0.45 & 0.47 & 0.44 & 0.44 & 0.47 & 0.51 & 0.54 & 0.50 & 0.47 & 0.42 & 0.42 & 0.43 \\
\hline Temperature, $^{\circ} \mathrm{C}$ & 19.84 & 20.67 & 20.23 & 19.72 & 20.69 & 21.19 & 21.25 & 22.03 & 21.69 & 19.95 & 19.19 & 19.26 \\
\hline Wind speed, $\mathrm{m} / \mathrm{s}^{\mathrm{N}}$ & 2.87 & 2.97 & 2.75 & 2.77 & 3.31 & 3.89 & 3.60 & 3.44 & 2.99 & 2.65 & 2.50 & 2.37 \\
\hline Precipitation, mm & 73 & 89 & 123 & 165 & 99 & 17 & 8 & 29 & 72 & 95 & 132 & 97 \\
\hline Wet days, d & 17.0 & 16.7 & 20.7 & 23.6 & 17.2 & 6.0 & 5.3 & 7.4 & 12.3 & 18.6 & 23.3 & 20.2 \\
\hline
\end{tabular}

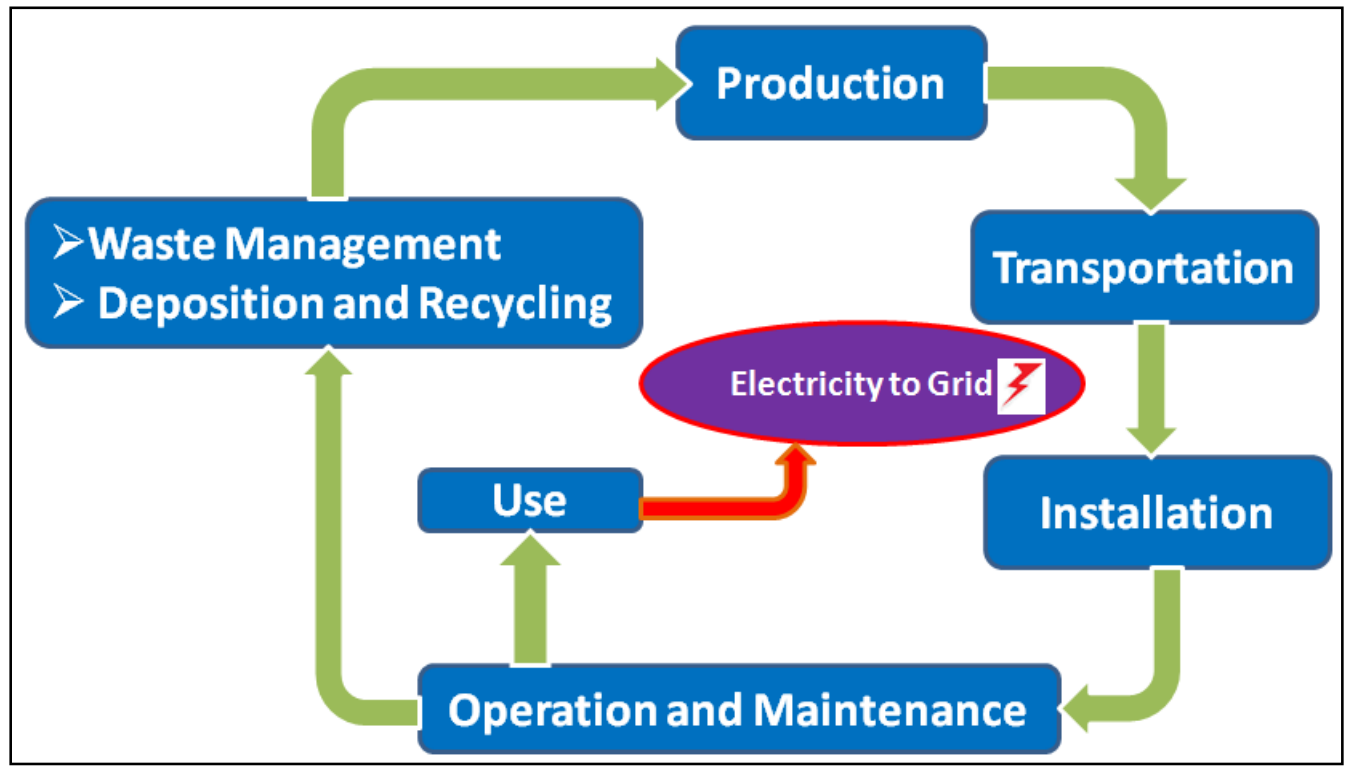

Figure 8. Stages of Life Cycle Analysis and Assessment for Rwamagana Solar power plant

\section{Environmental Impacts of Rwamagana Solar Power Plant}

The Rwamagana Solar power plant provides significant environmental benefits when compared to the conventional energy sources contributing to sustainable development. Using solar energy technologies has positive environmental implications such as reduction of the $\mathrm{CO}_{2}$ emissions, improvement of the quality of water supplies, reclamation of degraded land and a reduction of the number of the required power transmission lines. The following research questions were used in this study: what was on the surface before installing the PV system? What are the environmental effects of PV system? What is the social economic impact on the local community? And how do you do maintenance and how its effect on the environment? Figure 8 shows the flowchart of physical assessment of the power plant used in this study.

\section{Results and Discussion}

\subsection{System Installation, Operation and Maintenance Impact Assessment Results}

\subsubsection{System Installation}

In service, some solar panels get damaged. Break of glass for stone or heavy birds falling on solar panels, blowing diodes because of over-current caused a short circuit or lightning strokes are the most common damaging causes of the solar panels. The power plant had 95 damaged solar panels; there is a pressure on the power plants to reduce the number of damaged solar panels kept in the power plant station. The so-called damaged solar panels are not for throwing away, only their output power reduces for the degraded quality of the upper glasses. In some modules, the replacement of anti-return diodes is enough to bring back the so-called damaged solar panel in good conditions. Today's photovoltaic modules are safe and reliable products, with minimal failure rates and projected service lifetimes of 20 to 30 years.

\subsubsection{System Operation}

The most practical indicator of the performance of the solar PV systems can be obtained from the remote monitoring and data logging software supplied by most inverter manufacturers. The data logging software will record daily, monthly, and annual output for comparison of the actual system performance against the expected system performance. Solar PV systems require minimal 
maintenance, as they do not usually have moving parts. However, routine maintenance is required to ensure the solar PV system will continue to perform properly. The grid-connected PV system without battery storage technology is used. During the nighttime, the critical loads, including but not limited to safety lamps, camera systems, data recorders are supplied with electricity bought from Energy Utility Corporation Limited (EUCL) which was incorporated to have devoted attention in providing energy utility services in the Country through operations and maintenance of existing generation plants, transmission and distribution network and retail of electricity to end-users.

\subsubsection{System Maintenance}

It is therefore recommended that preventive inspection and maintenance works are undertaken every six to twelve months. The maintenance works activities and mitigation measures are summarized in table 5. PV modules require routine visual inspection for signs of damage, dirt build-up or shade encroachment. Solar PV system fixtures must be checked for corrosion (figure 10). This is to ensure that the solar PV system is safely secured. While the inverter's functionality can be remotely verified, only on-site inspection can verify the state of lightning surge arrestors, cable connection, and circuit breakers. The power plant used Polycrystalline (or multi-crystal) silicon panels have an electrifying return rate of about $12 \%-14 \%$ so they are less efficient. These panels are made up of lots of individual PV cells that have metal conducting materials nailed to the sides that will help excite the electrons and also connect the cells together. Polycrystalline silicon panels are the cheapest solar panels to produce, so they are usually the cheapest for consumers to buy. The maintenance costs of polycrystalline silicon panels are lower than the maintenance cost and if one of the cells on a polycrystalline panel is damaged, you can have the individual cell replaced without having to replace the entire panel. The annual variation of plant load factor is shown in figure 6 .

Table 5. Summary of some recommendations on the preventive maintenance works on the power plant

\begin{tabular}{|c|c|c|c|c|}
\hline $\mathbf{S} / \mathbf{N}$ & $\begin{array}{l}\text { Components/ } \\
\text { Equipment }\end{array}$ & Maintenance Activity & Mitigation Measures & Responsible \\
\hline 1 & PV modules & $\begin{array}{l}\text { 1. Check for dust/debris on surface of PV module } \\
\text { (Dust on the solar panels reduces the efficiency of } \\
\text { the system) } \\
\text { If the output power of the dirty small panel is } 5 \% \\
\text { lower than the power generated by the clean small } \\
\text { panel, it is an indication that the general cleaning of } \\
\text { all panels on the site is needed } \\
\text { 2. Check for Physical damage to any PV module } \\
\text { 3. Check for loose cable terminations between PV } \\
\text { modules, PV arrays, etc... } \\
\text { 4. Check for cable conditions }\end{array}$ & $\begin{array}{l}\text { 1. Wipe clean. Do not use any } \\
\text { solvents other than water and } \\
\text { the general cleaning is carried } \\
\text { out when } 5 \% \text { of efficiency } \\
\text { reduction are detected } \\
\text { 2. Replacement if found } \\
\text { damaged } \\
\text { 3. Retighten connection } \\
\text { 4. Replace cable if necessary }\end{array}$ & $\begin{array}{l}\text { Trained and } \\
\text { qualified } \\
\text { personnel } \\
+ \text { Plant Engineer }\end{array}$ \\
\hline 2 & $\begin{array}{c}\text { PV inverter } \\
\text { (Input voltage } \\
\text { 700VDC/ Output } \\
\text { voltage } 415 \mathrm{~V} \text { AC) }\end{array}$ & $\begin{array}{l}\text { 1.Check functionality e.g.: automatic disconnection } \\
\text { upon loss of grid power supply } \\
\text { 2. Check ventilation condition } \\
\text { 3. Check for loose cable terminations } \\
\text { 4. Check for abnormal operation temperature }\end{array}$ & $\begin{array}{l}\text { 1. Replacement if functionality } \\
\text { fails } \\
\text { 2. Clear dust and dirt in } \\
\text { ventilation system } \\
\text { 3. Tighten connection } \\
\text { 4. Replacement }\end{array}$ & $\begin{array}{l}\text { Trained and } \\
\text { qualified } \\
\text { personnel } \\
+ \text { Plant Engineer }\end{array}$ \\
\hline 3 & Cabling & $\begin{array}{l}\text { 1. Check for cable conditions i.e. wear and tear } \\
\text { 2. Check Cable terminals for burnt marks, hot spots } \\
\text { or loose connections }\end{array}$ & $\begin{array}{l}\text { 1. Replace cable if necessary } \\
\text { 2. Tighten connection or } \\
\text { replacement }\end{array}$ & $\begin{array}{l}\text { Trained and } \\
\text { qualified } \\
\text { personnel } \\
+ \text { Plant Engineer }\end{array}$ \\
\hline 4 & Junction boxes & $\begin{array}{l}\text { 1. Check cable terminals e.g. wear and tear or loose } \\
\text { connections } \\
\text { 2. Check for warning notices } \\
\text { 3. Check for physical damage }\end{array}$ & $\begin{array}{l}\text { 1. Tighten or replacement } \\
\text { 2. Replace warning notice if } \\
\text { necessary } \\
\text { 3. Replacement }\end{array}$ & $\begin{array}{l}\text { Trained and } \\
\text { qualified } \\
\text { personnel } \\
+ \text { Plant Engineer } \\
\end{array}$ \\
\hline 5 & Mission of isolation & Check functionality replacement & Recommend & $\begin{array}{l}\text { Trained and } \\
\text { qualified } \\
\text { personnel } \\
\end{array}$ \\
\hline 6 & $\begin{array}{c}\text { Earthing of solar PV } \\
\text { system }\end{array}$ & $\begin{array}{l}\text { 1. Check earthing cable conditions } \\
\text { 2.Check the physical earthing connection } \\
\text { 3. Check continuity of the cable to electrical earth }\end{array}$ & $\begin{array}{l}\text { 1. replacement } \\
\text { 2. Retighten connection } \\
\text { 3. Troubleshoot or replacement }\end{array}$ & $\begin{array}{c}\text { Trained and } \\
\text { qualified } \\
\text { personnel } \\
+ \text { Plant Engineer }\end{array}$ \\
\hline 7 & $\begin{array}{l}\text { Bonding of the } \\
\text { exposed metallic } \\
\text { structure of solar PV } \\
\text { system to lightning } \\
\text { earth } \\
\end{array}$ & $\begin{array}{l}\text { 1. Check bonding cable conditions } \\
\text { 2. Check physical bonding Connection } \\
\text { 3. Check continuity of the bonding to lightning earth }\end{array}$ & $\begin{array}{l}\text { 1. Replacement } \\
\text { 2. Tighten connection } \\
\text { 3. Troubleshoot or replacement }\end{array}$ & $\begin{array}{c}\text { Trained and } \\
\text { qualified } \\
\text { personnel } \\
+ \text { Plant Engineer }\end{array}$ \\
\hline
\end{tabular}




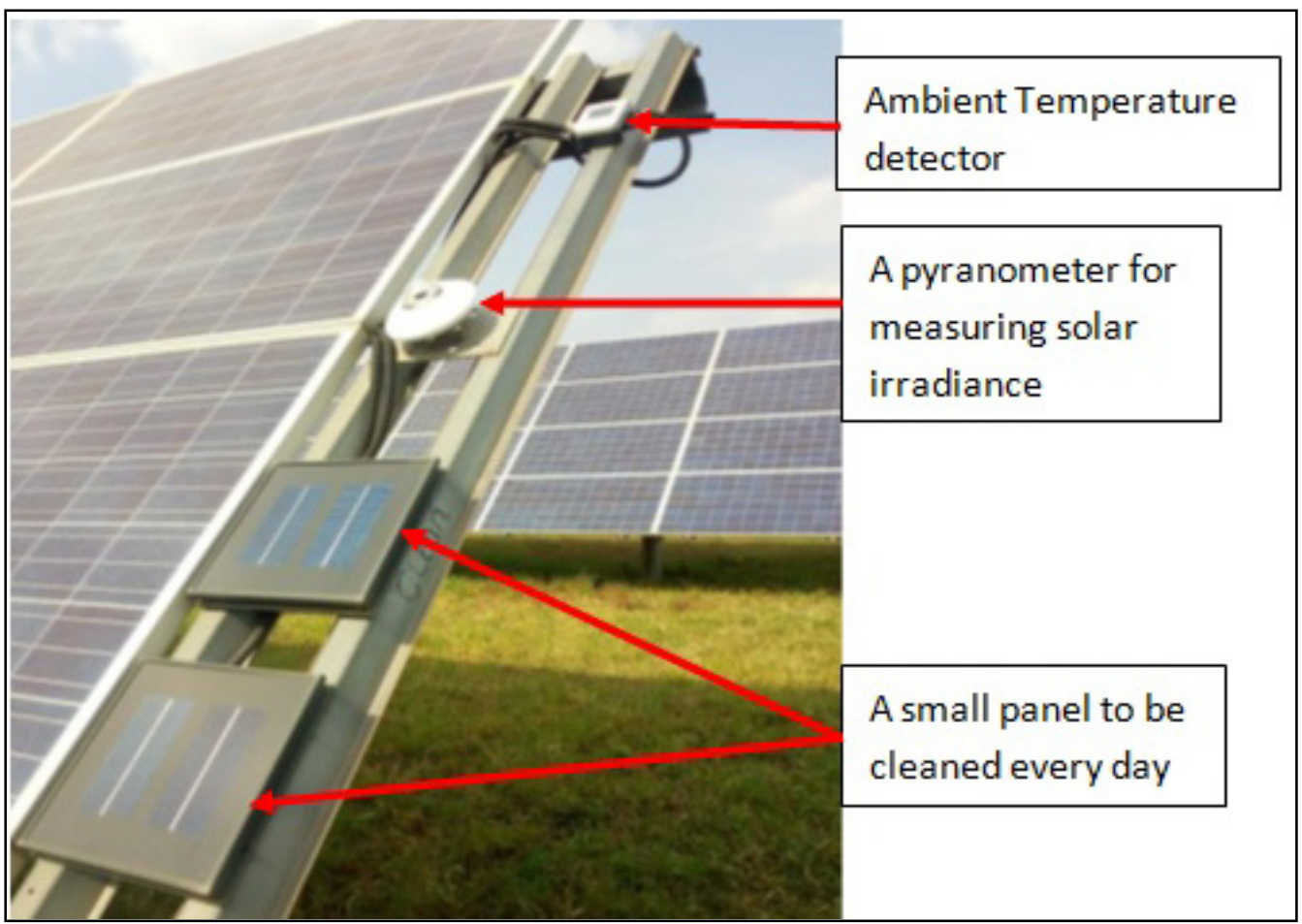

Figure 9. Efficiency detection solar panels
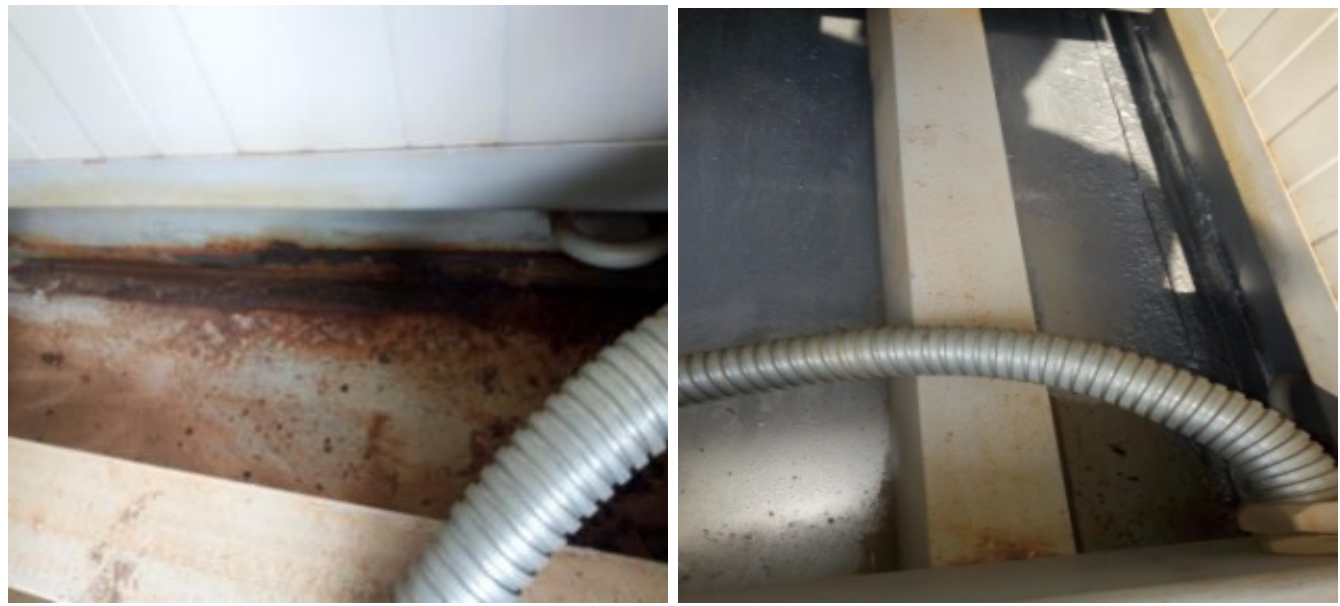

Figure 10. Before and after painting of inverter container

A solar cell can be operated at any point along with its characteristic current-voltage curve, as showed in figure 11. Two important points on this curve are the open-circuit voltage (Voc) and the short-circuit current (Isc). The open-circuit voltage is the maximum voltage at zero current, whereas the short-circuit current is the maximum current at zero voltage. For polycrystalline silicon solar cell used in Rwamagana solar power plant (Gigawatts) under standard test conditions, Voc is typically $45.19 \mathrm{~V}$, and Isc is typically $8.83 \mathrm{~A}$ for every square centimeter of the cell area. To a good approximation, Isc is proportional to the illumination level, whereas Voc is proportional to the logarithm of the illumination level. A plot of power (P) against voltage $(\mathrm{V})$ for this device shows that there is a unique point on the I-V curve at which the solar cell will generate maximum power. This is known as the maximum power point (Vmp, Imp). To maximize the power output, steps are usually taken during fabrication to maximize the three basic cell parameters: open-circuit voltage, short-circuit current and fill factor (FF). Note that Isc slightly increased linearly with temperature, but Voc and the maximum power Pm decrease with temperature and the working temperature of the plant performance is $45^{\circ} \mathrm{C}$. The working principle and monitoring methodology are shown in figure 5. A term describing how 'square' the I-V curve is, given by

$$
\text { FillFactor }=\frac{V_{m p} I_{m p}}{V_{o c} I_{s c}}=0.7518
$$




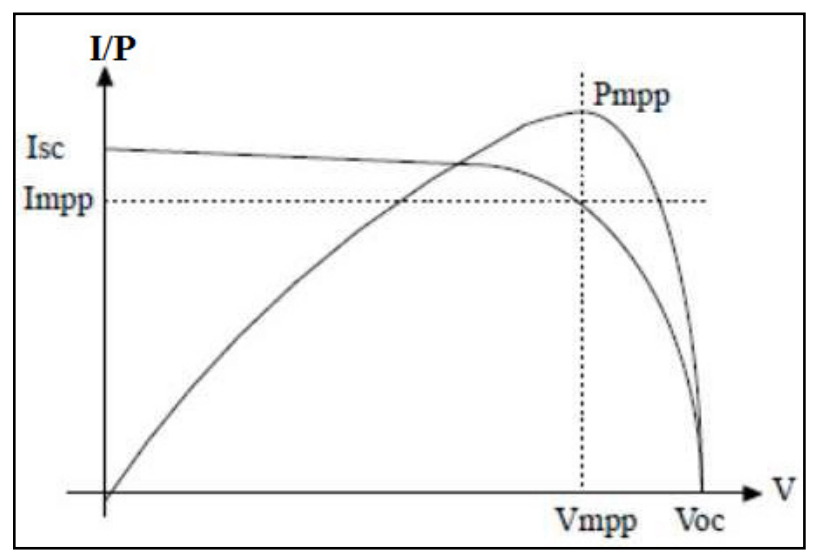

Figure 11. Intensity versus Voltage Characteristics of a solar cell

\subsection{Social-Economic, Health and Environmental Impact Assessment Results}

The Rwamagana solar power plant technology is located in Rwamagana district. The solar photovoltaic systems were expensive, especially the modules. However, they were economically attractive in the long term of their normal life, which needs little care and operational cost. Plant operations produce no greenhouse gases or noise and do not contribute to deforestation, erosion or desertification. The plant contributes $8.5 \mathrm{MW}$ to the national generation capacity via MUSHA Power lines. Based on a payback period of 20 years, which is also the expected average lifetime of a system, the electricity cost is approximately $0.26 \$ / \mathrm{kWh}$. The sun provides a tremendous resource for generating clean and sustainable electricity. The PV solar power plant has no potentially significant and irreversible environmental impacts but there some minor negative impacts of which are the removal of a portion of forest and wild animal which used live in there, the falling water from PV-panels decreases the rate of infiltration by causing the increase the drainage capacity. The installation of the solar power plant significantly reduces the amounts of greenhouse gases (GHGs) per year by displacing some of the need for the use of diesel for providing electricity. From the socio-economic viewpoint, there are some direct benefits are related to job creation for domestic and local communities/habitats. The power plant improves the quality of life because the local people are the ones who do basic maintenance like removing unwanted materials in water channels, grass cutting, cultivating the surrounding areas and it reduces migration. During installation and maintenance full- and part-time job creation opportunities improve local microeconomics and drive to poverty reduction. The Photovoltaic power generation can be used for the people live far from national grids and accelerate the rural electrification. It must take precautions before manipulating the $\mathrm{SF}_{6}$ (sulphur hexafluoride) circuit breaker installed into the substation. $\mathrm{SF}_{6}$ gas has excellent dielectric, arc quenching, chemical, and other physical properties which have proved its superiority over other arc quenching mediums such as oil or air. The technician must put on the gas flashing clothes to predict the maximum protection in case of gas leakage accident following switching on or off the circuit breaker. On a partly cloudy day, the PV module can produce up to $80 \%$ of its full solar power. It can produce about $30 \%$ power even with heavy clouds on an extremely overcast day. Snow rarely collects on the module, because it is angled to catch the sun. If snow collects, it quickly melts. Mechanically, the module withstands golf-ball-size hail. With increasing temperature, the short-circuit current of the cell increases, whereas the open-circuit voltage decreases. The effect of temperature on PV power is quantitatively evaluated by examining the effects of the current and the voltage separately.

The social, health and environmental benefits which accrue from replacing kerosene lanterns with solar PV alternatives and high prices of the PV systems, low affordability and challenges to provide financing solutions to the customers are the most frequently cited as being barriers. The solar power plant has a strong positive social impact on the Rwandan people. Supply of cleaning electricity generated suffices to power approximately 15,000-18,000 additional households. Further, the number of households provided with electricity could multiply significantly if the country's electrification rate were to increase due to improvements and expansion over time in the transmission and distribution grid.

\section{Conclusions}

A brief study on the Analysis of Environmental Impacts of Solar Energy Technologies in Rwanda is discussed along with a case study. Various instruments and parameter used in physical assessment of the plant is also dealt along with features. A case study in the Rwamagana solar power plant (GigaWatt) is briefly described in the paper highlighting the various physical assessments used. The plant provides significant socio-economic benefits to local communities and countrywide as it contributes an approximate $8.5 \mathrm{MW}$ to the national grid. They can accomplish significant emission reductions through photovoltaic electricity (PVe) production since PVs do not generate noise or chemical pollutants during their normal daily operation and maintenance. Solar power technology impacts the environment, which must be evaluated carefully to avoid the consequences of human development activities. The residents close to the power plant had a problem with excess water from solar panels destroying the community's activities and the power generated is not directly connected to them; it is sent to the utility and then gets distributed throughout the grid. The total energy produced is the $14 \mathrm{GWh} /$ year, and the households powered are 16000 , Carbon dioxide $\left(\mathrm{CO}_{2}\right)$ which means it is a waste product in our bodies and is also produced by burning fossil fuels and $\mathrm{CO}_{2}$ emissions avoided (tons) is 8000 . 
Solar photovoltaic (PV) technology contributes to grid-connected generation but also has a large scope of off-grid applications and suitable for rural electrification. The price of PV technology differs and depends on many factors, including system size, location, customer type, connected to an electric grid, technical specification and the extent to which end-user prices reflect the real costs of all the components. The power plant studied requires little more than occasional checking of apparatus and components whilst others will require a detailed maintenance schedule. Preventative maintenance should be regularly planned and human resources, in terms of available skilled technicians/ Engineer in the power plant, recycling technology are also lacking.

\section{REFERENCES}

[1] Republic of Rwanda, "Energy Sector Strategic Plan, 2018/19-2023/24" Ministry of infrastructure, Kigali, September 2018.

[2] https://globalsolaratlas.info/download/rwanda

[3] https://us.sunpower.com/what-solar-energy-and-how-do-sol ar-panels- work

[4] https://www.researchgate.net/figure/solar-home-system component_fig1_323737387

[5] https://www.mininfra.gov.rw/index.php?id=85

[6] https://www.reg.rw/facts-figures/facts-figures-details/facts/ of-households- with-access-to-electricity/

[7] http://www.reg.rw/what-we-do/generation/power-plant/

[8] NASA Langley Research Center Atmospheric Science Data
Center.

[9] New, M., Lister, D., Hulme, M. and Makin, I., 2002: A high-resolution data set of surface climate over global land areas. Climate Research 21.

[10] https://www.gaisma.com/en/location/rwamagana.html

[11] Various, (1996) 'Environmental Impacts from the Use of Solar Energy Technologies', THERMIE-BSTR/1000/96/H E project.

[12] Tsoutsos T. et al (1997) 'RES and environment' CRES, ALTENER Programme.

[13] Boyle G., Ed. (1996) 'Renewable Energy. Power for a Sustainable Future' The Open University, Oxford Press, London.

[14] Johansson T. B., Ed., Laurie Burnham, ex. Ed (1993) 'Renewable energy. Sources for Fuels and Electricity', Island Press.

[15] Tsoutsos T. (2001) 'Environmental Impact Assessment for Energy Projects', educational notes, Environmental Department, Technical University of Crete, Chania.

[16] ETSU (1996) 'The Environmental Implications of Renewables', Interim report for the UK Department of Trade and Industry, DTI, UK.

[17] OECD/IEA (1998) 'Benign Energy? The Environmental Implications of Renewables', International Energy Agency, Paris.

[18] Theodoratos P.C. and Karakasidis N.G. (1997) 'Hygiene Occupational Safety and Environmental protection', Ion, (in Greek).

[19] Renewable Energy Focus Handbook, Da Rosa (2005) Fundamentals of Renewable Energy Processes, 9780120885107

[20] https://www.reg.rw/what-we-do/offgrid-solutions/mini-gris/ 